\title{
PENGARUH PEMANASAN AWAL BAHAN BAKAR TERHADAP UNJUK KERJA MOTOR DIESEL DENGAN BAHAN BAKAR SOLAR DAN SOLAR DEX
}

\author{
Francisco Sarmento $^{1)}$, I Ketut Suarsana ${ }^{2)}$ \\ ${ }^{1}$ Jurusan Teknik Mesin, Program Magister, Universitas Udayana Denpasar Bali \\ francisco.sarmento@ymail.com \\ ${ }^{2}$ Jurusan Teknik Mesin, Universitas Udayana Denpasar Bali \\ ktsuarsana@yahoo.com
}

\begin{abstract}
ABSTRAK
Penggunaan pemanasan awal bahan bakar dapat meningkatkan kinerja mesin diesel. Pemanasan awal pada penelitian dilakukan dengan menggunakan panas heater. Parameter unjuk kerja mesin diesel meliputi: Torsi, daya, konsumsi bahan bakar, dan konsumsi bahan bakar spesifik masing-masing sebagai fungsi putaran poros. Peralatan yang digunakan dalam penelitian adalah mesin diesel empat langkah satu silinder merk Kubota kapasitas 82x82 type GA 90. Pengukuran dilakukan terhadap konsumsi bahan bakar dengan menggunakan fuel gauge, putaran poros menggunakan tachometer, waktu yang dibutuhkan untuk mengkonsumsi bahan bakar dengan stopwatch, mengukur beban yang dihasilkan dengan neraca beban dan mengukur suhu dengan thermometer. Hasil penelitian menghasilkan bahwa torsi, daya sebagai fungsi puturan poros lebih besar masing-masing 16,7\% dan 14,3\% dengan menggunakan pemanasan awal. Dari hasil penelitian ini menunjukkan bahwa dengan pemanasan awal pada bahan bakar dapat meningkatkan unjuk kerja mesin diesel.
\end{abstract}

Kata kunci: bahan bakar, pemanasan awal, unjuk kerja.

\section{PENDAHULUAN}

Motor diesel banyak di gunakan sebagai alat transportasi baik di darat maupun di air, seperti truk, lokomotif kereta, perahu dan kapal laut. Mesin diesel konstruksinya lebih sederhana dan biaya operasional lebih rendah, sehingga pemakaian mesin diesel lebih banyak disukai dari pada mesin uap atau mesin listrik. Dalam instalasi yang membutuhkan daya besar digunakan untuk menghasilkan arus listrik atau menggerakan kapal, biasanya pilihan jatuh pada mesin diesel.Karakteristik utama dari mesin diesel yang membedakannya dari motor bakar yang lain adalah metode penyalaan bahan bakar. Dalam mesin diesel bahan bakar di injeksikan kedalam silinder yang berisi udara bertekanan tinggi. Sedangkan bersediaan akan bahan bakar solar semakin menipis, maka perlu dicarikan alternative pengganti bahan bakar disamping menggunakan teknologi lain yang dapat menghemat penggunaan bahan bakar tersebut, di antara jenis bahan bakar alternative yang sudah beredar di pasaran adalah bahan bakar solar dex. Solar dex adalah bahan bakar pengganti solar yang diproduksi oleh pertamina dan sudah beredar di pasaran, sedangkan pemanasan awal bahan bakar adalah metode yang digunakan untuk menghemat pengunaan bahan bakar serta memperbaiki unjuk kerja motor diesel dengan memanfaatkan panas air dari radiator sehingga bahan bakar akan menjadi jenuh dan mengakibatkan suhu bahan bakar mendekati titik nyalanya, sehingga mudah terbakar (Wiranto, A. \& Koichi, T. 1986). Pemanasan awal bahan bakar yang digunakan sudah banyak beredar dipasaran yang bernama heater/preheater. fungsi putaran poros. Diharapkan dari hasil yang diperoleh dapat dijadikan acuan atau perbandingan dalam pengamatan lainnya. Tujuan penelitian adalah untuk mendapatkan perbandingan unjuk kerja motor diesel dengan bahan bakar solar dan solar dex dengan dan tanpa pemanasan awal yang meliputi: torsi, daya, konsumsi bahan bakar dan konsumsi bahan bakar spesifik sebagai putaran poros. Pendapat dari peneliti sebelumnya menyatakan bahwa untuk mengetahui karakteristik: (1) konsumsi bahan bakar motor diesel 4 langkah ditinjau dari perubahan timing injeksi pada penggunaan biosolar dan Pertamina Dex, (2) 
opasitas gas buang pada motor diesel yang dihasilkan ditinjau dari perubahan timing injeksi pada penggunaan biosolar dan pertamina dex. Penelitian dilakukan dengan pendekatan eksperimen pada motor diesel 4 langkah 1 silinder direct injection berdaya maksimum 4200 watt. Pengontrolan dilakukan pada putaran dan beban mesin melalui beban kelistrikan dari generator (Wardan Suyanto,. dkk 2015). Dengan meningkatnya harga minyak dunia dan semakin besarnya kebutuhan energi terutama bahan bakar fosil maka diperlukanya energi alternatif atau pengganti untuk mengantisipai cadangan sumber minyak bumi yang semakin menipis. Terobosan di dalam penggunaan sumber daya alam yang dapat diperbaharui dan kemajuan teknologi di bidang (Aldino Yanuar Habibie,. dkk 2015). Pada setiap bahan bakar mempunyai kecenderungan yang sama. Pada putaran $1200 \mathrm{rpm}$ sampai dengan putaran $1800 \mathrm{rpm}$ torsi beranjak naik seiring dengan putaran mesin permenitnya, itu menunjukan kekuatan putar mesin maksimal pada rpm 1800 dengan nilai 8,95 Nm untuk bahan bakar Pertamina Dex, 8,76 Nm untuk bahan bakar Shell Diesel, 8,63 Nm untuk bahan bakar Total Diesel. Bahan bakar Pertamina Dex memiliki torsi paling tinggi dibandingkan dengan bahan bakar yang lain, dikarnakan Pertamina Dex memiliki cetane number paling tinggi dengan angka 53 (Imron Rosyadi,. dkk 2015). The performance and emission characteristics of any engine are highly affected by the spray characteristics of the fuel. In diesel engine the fuel is injected at highpressure to overcome the air resistance (back pressure) to get penetrated into the chamber. High pressure is also needed to enhance the atomization and spray penetration of the injected fuel and also to improve the combustion efficiency (Vijayakumar Tulasi,. At all 2013). Under ideal conditions the common internal combustion engine burns the fuel/air mixture in the cylinder in an orderly and controlled fashion, the thermal extension of the range in proximity of the valve and other valve of the cylinder is different and so the distortion of the geometry of the cylinder liner surface force the designer to make the clearance between the piston and the cylinder liner bigger (Sahu Ravikant,. At all 2014).

\section{METODE PENELITIAN}

\section{Bahan penelitian}

Bahan bakar solar dan solar dex, bersediaan akan bahan bakar solar semakin menipis, maka perlu dicarikan alternative pengganti bahan bakar disamping menggunakan teknologi lain yang dapat menghemat penggunaan bahan bakar tersebut, di antara jenis bahan bakar alternative yang sudah beredar di pasaran adalah bahan bakar solar dex. Solar dex adalah bahan bakar pengganti solar yang diproduksi oleh pertamina dan sudah beredar di pasaran, sedangkan pemanasan awal bahan bakar adalah metode yang digunakan untuk menghemat pengunaan bahan bakar serta memperbaiki unjuk kerja motor diesel dengan memanfaatkan panas air dari radiator sehingga bahan bakar akan menjadi jenuh dan mengakibatkan suhu bahan bakar mendekati titik nyalanya, sehingga mudah terbakar. Pemanasan awal bahan bakar yang digunakan sudah banyak beredar dipasaran yang bernama heater/preheater. fungsi putaran poros.

\section{Alat penelitian}

1. Fuel gauge yaitu, pada dasarnya tabung yang di dalam dibatasi dengan jarak dan setiap jarak berurutan mempunyai volume masing-masing 25, 50 dan $100 \mathrm{ml}$.

2. Piringan rem yaitu, media penghubung system dengan batang prony break, pengereman pada saat dilakukan penelitian.

3. Sepatu rem yaitu, alat yang digunakan untuk melakukan penekanan dengan dua baut berulir yang terletak disisi kiri dan kanan pada piringan pengereman. 
4. Neraca beban yaitu, berfungsi untuk mengukur beban yang di hasilkan oleh prony break.

5. Thermometer yaitu, untuk mengukur suhu air radiator yang dimasukan ke dalam selang radiator, untuk mengetahui panas air radiator yang terbaca pada skala ukur thermometer.

6. Stopwatch yaitu, alat ukur waktu pemakaian bahan bakar dan mempunyai batas ukur terkecil sampai 0,1 detik.

7. Tachometer yaitu, untuk mengukur putaran poros penggerak.

Perbandingan unjuk kerja motor diesel dengan bahan bakar solar dan solar dex dengan dan tanpa pemanasan awal yang meliputi, torsi, daya, konsumsi bahan bakar dan konsumsi bahan bakar spesifik sebagai fungsi putaran poros.

\section{Siklus kerja motor diesel}

Dibagi menjadi 2, yaitu motor diesel dua langkah dan motor diesel empat langkah. Yang di bahas dalam penelitian ini adalah motor diesel empat langkah terdiri dari langkah hisap, langkah kompresi, langkah kerja atau ekspansi dan langkah buang, sperti terlihat pada gambar 1 berikut:

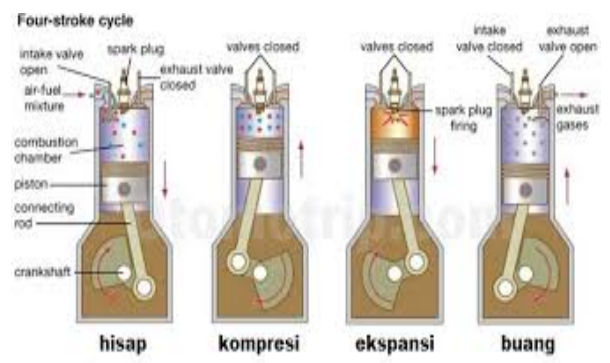

Gambar 1. Langkah kerja motor diesel empat langkah

\section{Siklus ideal}

Prosese thermodinamika dan kimia yang terjadi didalam motor bakar torak sangat kompleks untuk di analisis secara teori, maka untuk memudahkan menganalisis proses tersebut di perlukan suatu bayangan keadaan yang ideal. Makin ideal suatu keadaan makin mudah untuk di analisis, akan tetapi makin jauh menyimpang dari keadaan sebenarnya. Pada umumnya untuk menganalisis proses thermodinamika yang terjadi pada motor bakar digunakan siklus udara sebagai siklus ideal, seperti pada gambar 2 dan 3 berikut:

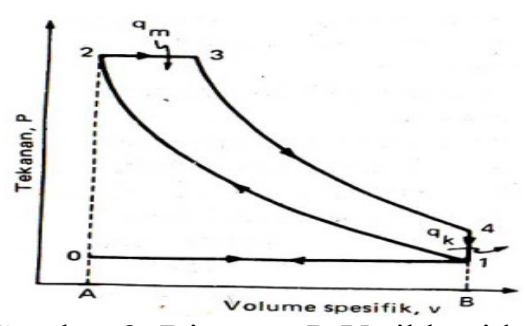

Gambar 2. Diagram P-V siklus ideal

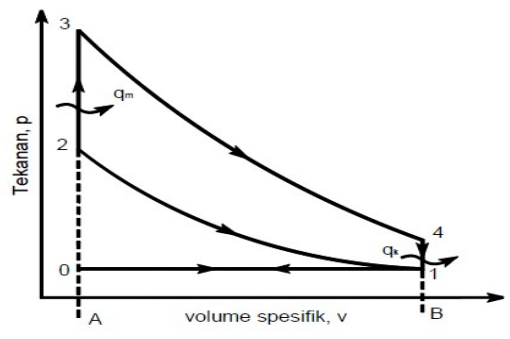

Gambar 3. Diagram P-V siklus dual

\section{Daya indikator}

Daya yang di hasilkan didalam silinder dinamakan daya indicator. Sedangkan kerja setiap siklus ditentukan dengan mengukur luas diagram P-V dari siklus sebenarnya. Diagram P-V tersebut 
diperoleh sebagai hasil pengukuran tekanan gas didalam silinder dengan mempergunakan alat pengukuran khusus yang dibuat untuk keperluan tersebut, diagram P-V tersebut diatas dinamakan diagram indicator dan kerja setiap siklus ditentukan oleh diagram indikator dinamakan kerja indikator (wi) tekanan efektif rata-ratanya dinamakan tekanan efektif rata-rata indikator $\left(\mathrm{P}_{\text {rata-rata }}\right)$. Jika harga $\left(\mathrm{P}_{\text {rata-rata }}\right.$ diketahui, maka daya indikator dapat dihitung dengan mempergunakan persamaan sebagai berikut:

$N t=\frac{\frac{\pi}{4} P r \cdot \mathrm{D}^{2} \cdot S \cdot Z \cdot a \cdot n}{60.1000}$

Dengan: $\mathrm{Ni}=$ Daya indikator motor $(\mathrm{Kw}), \mathrm{P}_{\mathrm{r}}=$ Tekanan efektif rata-rata indikator $\left(\mathrm{N} / \mathrm{m}^{2}\right), \mathrm{D}=$ Diameter lubang silinder $(\mathrm{m}), \mathrm{n}=$ putaran poros engkol (rev/min), $\mathrm{S}=$ Langkah torak (m), $\mathrm{Z}=$ Jumlah silinder , A = Jumlah siklus per putaran.

\section{Torsi}

Torsi dan daya merupakan suatu factor yang memegang peranan sangat penting dalam menentukan unjuk kerja mesin. Jika daya motor naik, maka torsi juga akan naik. Pengoperasian yang mencapai beban penuh akan diikuti dengan kenaikan daya poros samapai maksimum. Jika beban ditambah terus daya poros akan menurun, sedangkan torsi motor masih bisa bertambah, sehinga pada posisi tertentu akan mencapai torsi maksimum. Kemudian torsi motor dengan daya poros secara matematis ditulis sebagai berikut:

$$
\mathrm{T}=\mathrm{F} \times \mathrm{L}, \mathrm{F}=\mathrm{m} \times \mathrm{g}, \mathrm{T}=\mathrm{m} \times \mathrm{g} \times \mathrm{L}
$$

Dengan $\mathrm{T}=$ Torsi $(\mathrm{Nm}), \mathrm{F}=$ Gaya $(\mathrm{N}), \mathrm{L}=$ Jarak $(\mathrm{m}), \mathrm{m}=$ massa beban $(\mathrm{Kg}), \mathrm{g}=$ percepatan gravitasi $\left(\mathrm{m} / \mathrm{s}^{2}\right)$

\section{Daya poros}

Pada motor bakar torak daya yang dipergunakan adalah daya poros karena poros tersebut yang menggerakan beban. Daya poros di bangkitkan oleh daya indikator yang merupakan daya gas pembakaran yang mengerakan piston. Sebagian daya indikator dibutuhkan untuk mengatasi gesekan mekanik, misalnya gesekan antara piston dengan dinding silinder dan gesekan poros dengan bantalannya. Peralatan yang digunakan untuk mengukur daya poros pada motor diesel didalam penelitian ini dilakukan dengan menggunakan prony break, maka untuk mengukur besarnya daya dapat dilakukan dengan menggunakan persamaan berikut:

$P=\frac{2 \pi \cdot \mathrm{n} \cdot \mathrm{T}}{60 \times 1000}$

maka: $\mathrm{P}=\frac{2 \pi \cdot n \cdot F \cdot L}{60 \times 1000}$

Dengan: $\mathrm{P}=$ Daya poros $(\mathrm{kW}), \mathrm{n}=$ Putaran poros $(\mathrm{rev} / \mathrm{min})$

\section{Konsumsi bahan bakar}

Bahan bakar yang dibutuhkan dalam waktu tertentu dapat diukur dengan menggunkan plint fuel gauge. Konsumsi bahan bakar yang dibutuhkan dihitung dengan persamaan berikut: 
Vol. 1, No. 1, April 2017: hlm 132-141

$\mathrm{Vb}=\frac{3600 . \mathrm{Vg}}{t} \times \frac{1}{1000}$

Dengan: $\mathrm{Vb}=$ konsumsi bahan bakar (liter $/ \mathrm{h}), \mathrm{Vg}=$ volume bahan bakar (liter), $\mathrm{t}=$ waktu pembakaran (s).

Komsumsi bahan bakar spesifik

Konsumsi bahan bakar spesifik yang di butuhkan, dapat di hitung dengan persamaan berikut:

$\mathrm{SFCe}=\frac{V b}{P}$

Dengan: SFCe=konsumsi bahan bakar spesifik (liter/kW.h), $\mathrm{Vb}=$ konsumsi bahan bakar (liter/h), $\mathrm{P}=$ daya poros $(\mathrm{kW})$

\section{HASIL DAN PEMBAHASAN}

Pengujian motor diesel dengan menggunakan bahan bakar solar dan solar dex dilakukan pada putaran poros motor $700 \mathrm{rev} / \mathrm{min}$ sampai dengan $2500 \mathrm{rev} / \mathrm{min}$ dengan diberikan beban pengereman menggunakan prony brake sebesar $2 \mathrm{~kg}$. pada putaran poros motor tersebut dilakukan pencatatan waktu pemakaian bahan bakar $(\mathrm{t})$, beban pengereman $(\mathrm{m})$ dan konsumsi bahan bakar $(\mathrm{Vb})$. Dalam pengujian ini dilakukan pengaruh pemanasan awal bahan bakar terhadap unjuk kerja motor diesel dengan bahan bakar solar dan solar dex. Data hasil pengujian unjuk kerja motor diesel menggunakan bahan bakar solar dengan pemanasan dan tanpa pemanasan awal di berikan pada tabel berikut:

Tabel 1. data hasil pengujian bahan bakar solar sebagai fungsi putaran poros

\begin{tabular}{cccccccc}
\hline $\begin{array}{c}\mathrm{N} \\
\mathrm{o}\end{array}$ & $\begin{array}{c}\mathrm{n} \\
(\mathrm{rev} / \mathrm{min})\end{array}$ & $\begin{array}{c}\mathrm{m} \\
(\mathrm{kg})\end{array}$ & $\begin{array}{c}\mathrm{t} \\
(\mathrm{s})\end{array}$ & $\begin{array}{c}\mathrm{T} \\
(\mathrm{N} . \mathrm{m})\end{array}$ & $\begin{array}{c}\mathrm{P} \\
(\mathrm{kW})\end{array}$ & $\begin{array}{c}\mathrm{Vb} \\
(1 / \mathrm{h})\end{array}$ & $\begin{array}{c}\text { SFCe } \\
(1 / \mathrm{kW} . \mathrm{h})\end{array}$ \\
\hline 1 & 700 & 2 & 34,96 & 5,886 & 1,4312 & 6,2059 & 0,775 \\
\hline 2 & 900 & 2,5 & 22,55 & 7,3575 & 0,6930 & 0,3192 & 0,4606 \\
\hline 3 & 1100 & 2,6 & 18,48 & 7,6518 & 0,8809 & 0,3896 & 0,4422 \\
\hline 4 & 1300 & 2,6 & 15,95 & 7,6518 & 1,0411 & 0,4514 & 0,4335 \\
\hline 5 & 1500 & 2,7 & 13,79 & 7,9461 & 1,2475 & 0,5221 & 0,4185 \\
\hline 6 & 1700 & 2,7 & 13,09 & 7,9461 & 1,4138 & 0,5500 & 0,3890 \\
\hline 7 & 1900 & 2,8 & 10,31 & 8,2404 & 1,6387 & 0,6983 & 0,4261 \\
\hline 8 & 2100 & 3,1 & 9,60 & 9,1233 & 2,0053 & 0,75 & 0,3740 \\
\hline 9 & 2300 & 3,2 & 8,41 & 9,4176 & 2,2671 & 0,8561 & 0,3776 \\
\hline 10 & 2500 & 3,5 & 7,62 & 10,3005 & 2,6952 & 0,9448 & 0,3505 \\
\hline
\end{tabular}


Tabel 2. Data hasil pengujian bahan bakar solar dex sebagai fungsi putaran poros

\begin{tabular}{cccccccc}
\hline No & $\begin{array}{c}\mathrm{n} \\
(\mathrm{rev} / \mathrm{min})\end{array}$ & $\begin{array}{c}\mathrm{m} \\
(\mathrm{kg})\end{array}$ & $\begin{array}{c}\mathrm{t} \\
(\mathrm{s})\end{array}$ & $\begin{array}{c}\mathrm{T} \\
(\mathrm{N} . \mathrm{m})\end{array}$ & $\begin{array}{c}\mathrm{P} \\
(\mathrm{kW})\end{array}$ & $\begin{array}{c}\mathrm{Vb} \\
(1 / \mathrm{h})\end{array}$ & $\begin{array}{c}\text { SFCe } \\
(1 / \mathrm{kW} . \mathrm{h})\end{array}$ \\
\hline 1 & 700 & 2 & 47,12 & 5,886 & 0,4312 & 0,1528 & 0,3543 \\
\hline 2 & 900 & 2,3 & 34,48 & 6,7689 & 0,6376 & 0,2088 & 0,3274 \\
\hline 3 & 1100 & 2,3 & 26,45 & 6,7689 & 0,7793 & 0,2722 & 0,3492 \\
\hline 4 & 1300 & 2,5 & 24,90 & 7,3575 & 1,0011 & 0,2891 & 0,2887 \\
\hline 5 & 1500 & 2,7 & 23,87 & 7,9461 & 1,2475 & 0,3016 & 0,2417 \\
\hline 6 & 1700 & 2,7 & 19,63 & 7,9461 & 1,4138 & 0,3667 & 0,2593 \\
\hline 7 & 1900 & 3 & 18,26 & 8,829 & 1,7557 & 0,3943 & 0,2245 \\
\hline 8 & 2100 & 3,3 & 18,14 & 9,7119 & 2,1346 & 0,3969 & 0,1859 \\
\hline 9 & 2300 & 3,3 & 17,47 & 9,7119 & 2,3379 & 0,4121 & 0,1762 \\
\hline 10 & 2500 & 3,5 & 17,05 & 10,3005 & 2,6952 & 0,4222 & 0,1566 \\
\hline
\end{tabular}

\section{Pembahasan}

Data hasil pengukuran yang berupa massa, waktu yang ditentukan untuk menghabiskan sejumlah bahan bakar dan putaran poros digunakan untuk menghasilkan torsi, daya konsumsi bahan bakar dan bahan bakar spesifik masing-masing dengan menggunakan bahan bakar solar dan solar dex dengan dan tanpa pemanasan awal.

Hasil pengolahan data dari pengukuran di peroleh torsi sebagai fungsi putaran poros motor dengan menggunakan bahan bakar solar dan solar dex dengan dan tanpa pemanasan awal dalam bentuk grafik di berikan pada gambar berikut:

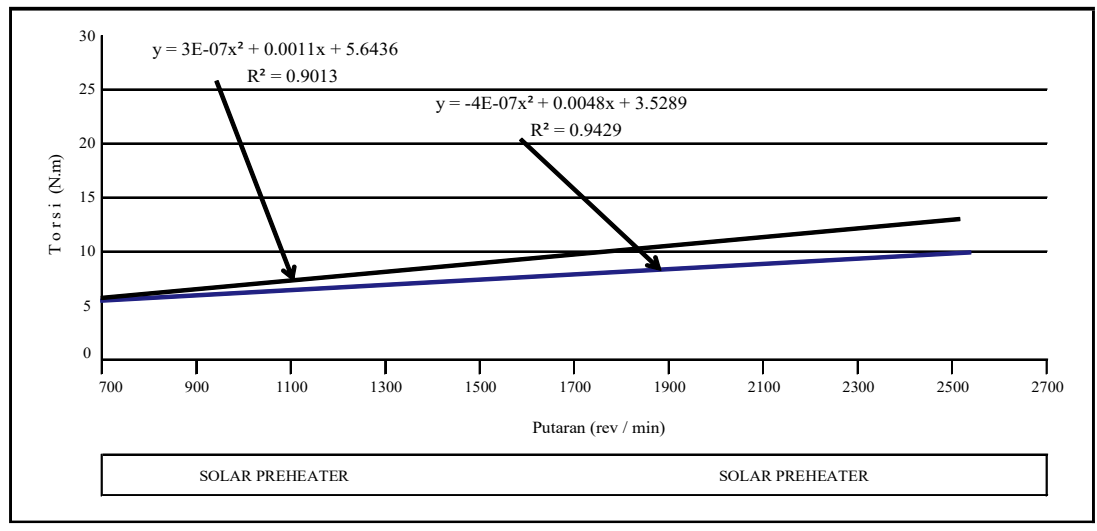

Gambar 4. Torsi sebagai fungsi putaran poros menggunakan bahan bakar solar dengan dan tanpa preheater

Pengukuran dilakukan pada putaran poros motor $700 \mathrm{rev} / \mathrm{min}$ sampai $2500 \mathrm{rev} / \mathrm{mm}$ dengan kenaikan putaran poros mesin $200 \mathrm{rev} / \mathrm{min}$. Terlihat dalam grafik torsi bergerak naik dengan bertambah besarnya putaran poros baik menggunakan bahan bakar solar tanpa preheater maupun solar dengan preheater. Torsi dengan bahan bakar solar tanpa preheater mengikuti persamaan y $=-312-07 \mathrm{x}^{2}+0.0011 \mathrm{x}+5.6436$ dengan koefisien korelasi $\mathrm{r}^{2}=0,9013$. torsi dengan bahan bakar solar dengan preheater mengikuti persamaan $\mathrm{y}=-4 \mathrm{e}-07 \mathrm{x} 2+0.0048 \mathrm{x}+3.5289$ dengan koefisien korelasi $\mathrm{r}^{2}=0,9429$. pada putaran $700 \mathrm{rev} / \mathrm{min}$ torsi antara bahan bakar solar dengan preheater dan solar tanpa preheater memiliki nilai torsi yang sama. kemudian perbedaan nilai torsi antara kedua bahan bakar tersebut meningkat lebih tinggi pada putaran $1200 \mathrm{rev} / \mathrm{min}$ sampai dengan $2500 \mathrm{rev} / \mathrm{min}$. nilai torsi tertinggi antara bahan bakar solar dengan preheater dengan bahan bakar 
solar tanpa preheater terjadi pada putaran $2100 \mathrm{rev} / \mathrm{min}$ dengan peningkatan torsi rata-rata meningkat sebesar $16,7 \%$. hal ini terjadi karena solar yang mengalami pemanasan awal sudah menjadi jenuh dan suhunya menjadi lebih tinggi setelah melewati preheater, sehingga pembakaran lebih mudah dilakukan dan hasilnya lebih baik.

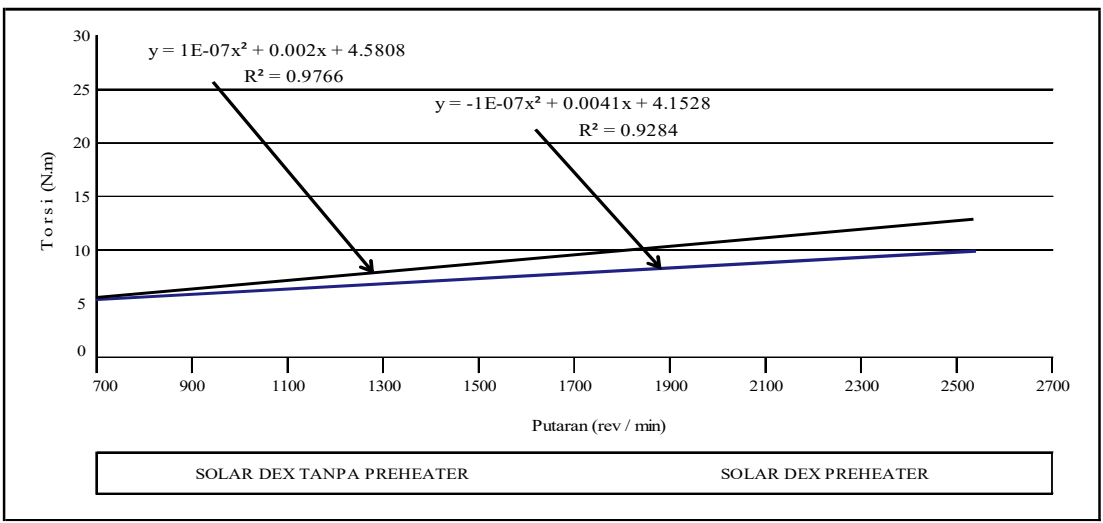

Gambar 5.Torsi sebagai fungsi putaran poros motor menggunakan bahan bakar solar dex tanpa dan dengan preheater

Pengukuran data dilakukan pada putaran poros motor $700 \mathrm{rev} / \mathrm{min}$ sampai $2500 \mathrm{rev} / \mathrm{min}$ dengan kenaikan putaran poros mesin $200 \mathrm{rev} / \mathrm{min}$. Terlihat dalam grafik torsi bergerak naik dengan bertambah besarnya putaran poros baik menggunakan bahan bakar solar dex tanpa preheater maupun solar dex dengan preheater.Torsi dengan bahan bakar solar dex tanpa preheater mengikuti persamaan $\mathrm{y}=1 \mathrm{E}-07 \mathrm{x}^{2}+0,002 \mathrm{x}+4.5808$ dengan koefisien korelasi $\mathrm{R}^{2}=0,9766$. Torsi dengan bahan bakar solar dex dengan preheater mengikuti persamaan $\mathrm{y}=$-IE- $07 \mathrm{x}^{2}+0,004 \mathrm{~h}$ +4.1528 dengan koefisien korelasi $\mathrm{R}^{2}=0,9284$. Pada putaran $700 \mathrm{rev} / \mathrm{min}$ sampai dengan 900 rev/min nilai torsi antara bahan bakar solar dex dengan preheater dan solar dex tanpa preheater memiliki nilai torsi yang tidak jauh berbeda. Kemudian perbedaan nilai torsi antara kedua bahan bakar tersebut meningkat lebih tinggi pada putaran $1500 \mathrm{rev} / \mathrm{min}$ sampai dengan $2500 \mathrm{rev} / \mathrm{min}$. Nilai perbedaan torsi tertinggi antara bahan bakar solar dex dengan preheater dan bahan bakar solar dex tanpa preheater terjadi pada putaran $2100 \mathrm{rev} / \mathrm{min}$ dengan peningkatan torsi rata-rata meningkat sebesar $14,28 \%$.

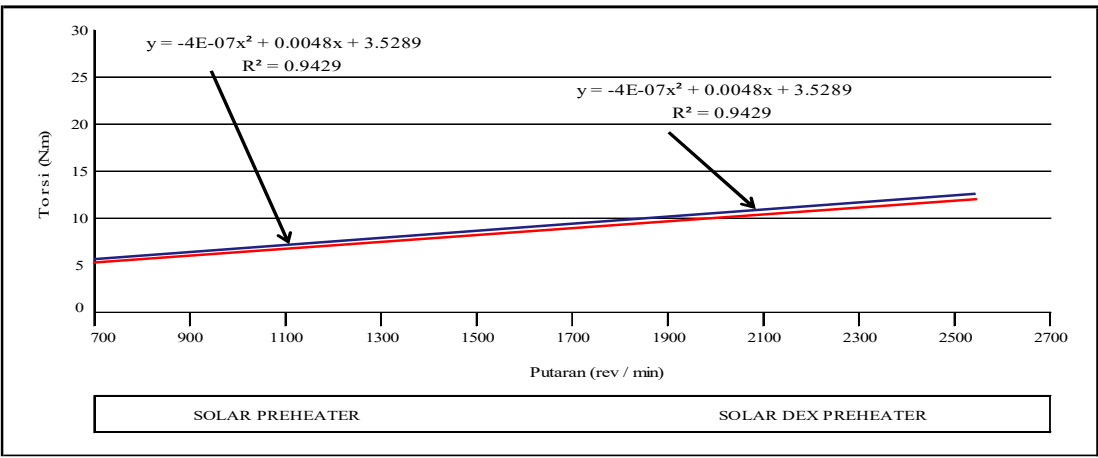

Gambar 7. Solar sebagai fungsi putaran poros motor menggunakan bahan bakar solar dan solar dex dengan menggunakan preheater 
Pengukuran data dilakukan pada putaran poros motor $700 \mathrm{rev} / \mathrm{min}$ sampai $2500 \mathrm{rev} / \mathrm{min}$ dengan kenaikan putaran poros mesin $200 \mathrm{rev} / \mathrm{min}$. Terlihat dalam grafik torsi bergerak naik dengan bertambah besarnya putaran poros baik menggunakan bahan bakar solar preheater maupun solar dex preheater.Torsi dengan bahan bakar solar menggunakan preheater mengikuti persamaan $\mathrm{y}=$ $4 \mathrm{E}-07 \mathrm{x}^{2}+0,0048 \mathrm{x}+3.5289$ dengan koefisien korelasi $\mathrm{R}^{2}=0,9429$. Torsi dengan bahan bakar solar dex menggunakan preheater mengikuti persamaan $\mathrm{y}=-\mathrm{IE}-07 \mathrm{x} 2+0,0041 \mathrm{x}^{\prime}+4.1528$ dengan koefisien korelasi $\mathrm{R}^{2}=0,9284$. Pada putaran $700 \mathrm{rev} / \mathrm{min}$ torsi antara bahan bakar solar dengan preheater dan solar tanpa preheater memiliki nilai torsi yang sama. Kemudian perbedaan nilai torsi antara kedua bahan bakar tcrsebut meningkat lebih tinggi pada putaran $1100 \mathrm{rev} / \mathrm{min}$ sampai dengan $2500 \mathrm{rev} / \mathrm{min}$. Nilai torsi tertinggi antara bahan bakar solar dengan preheater dengan bahan bakar solar dex menggunakan preheater terjadi pada putaran $2100 \mathrm{rev} / \mathrm{min}$ dengan peningkatan torsi rata-rata meningkat sebesar $14,3 \%$.

Hasil pengolahan data dari pengukuran diperoleh daya sebagai fungsi putaran poros motor, grafiknya diberikan pada Gambar berikut:

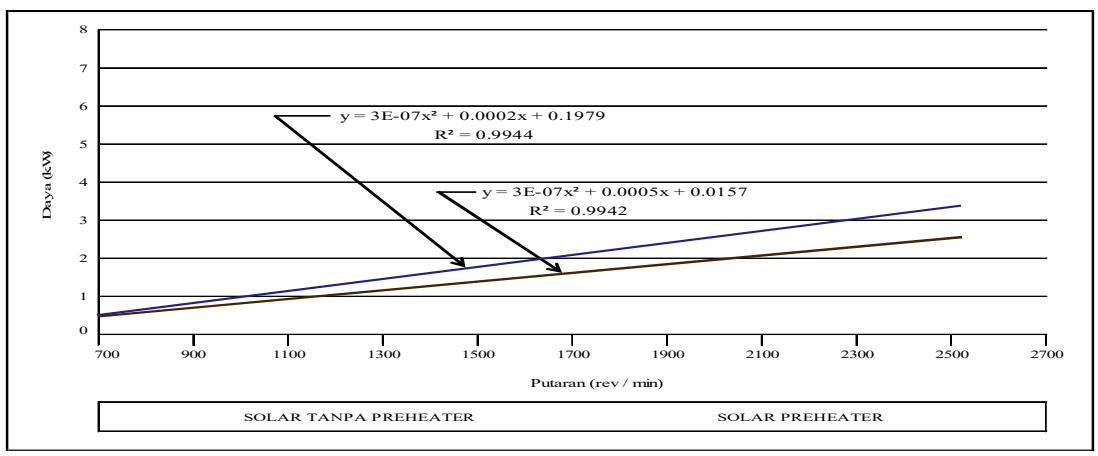

Gambar 8. Daya sebagai fungsi putaran poros motor menggunakan bahan bakar solar tanpa dan dengan preheater

Pengukuran data dilakukan pada putaran poros motor $700 \mathrm{rev} / \mathrm{min}$ sampai $2500 \mathrm{rev} / \mathrm{min}$ dengan kenaikan putaran poros mesin $200 \mathrm{rev} / \mathrm{min}$. Terlihat dalam grafik daya bergerak naik dengan bertambah besarnya putaran poros baik menggunakan bahan bakar solar tanpa preheater maupun solar dengan preheater. Daya dengan bahan bakar solar tanpa preheater maupun solar dengan preheater mengikuti persamaan $\mathrm{y}=3 \mathrm{E}-07 \mathrm{x}^{2}+0,0002 \mathrm{x}+0,1979$ dengan koefisien korelasi $\mathrm{R}^{2}=0,9944$. Daya dengan bahan bakar solar dengan preheater mengikuti persamaan $\mathrm{y}=3 \mathrm{E}-07 \mathrm{x} 2+$ $0,0005 \mathrm{x}+0,0157$ koefisien korelasi $\mathrm{R} 2=0,9942$. Pada putaran $700 \mathrm{rev} / \mathrm{min}$ sampai 1100 rev/min daya antara bahan bakar solar dengan preheater dan solar tanpa preheater daya yang cenderung sama. Kemudian perbedaan nilai daya antara kedua bahan bakar tersebut meningkat lebih tinggi pada putaran $1500 \mathrm{rev} / \mathrm{min}$ sampai dengan $2100 \mathrm{rev} / \mathrm{min}$. Nilai perbedaan daya tertinggi antara bahan bakar solar dengan preheater dengan bahan bakar solar tanpa preheater terjadi pada putaran $2100 \mathrm{rev} / \mathrm{min}$ dengan peningkatan daya rata-rata sebesar $14,3 \%$. Hal ini terjadi karena solar yang mengalami pemanasan awal sudah menjadi jenuh dan suhunya menjadi lebih tinggi setelah melewati preheater. 


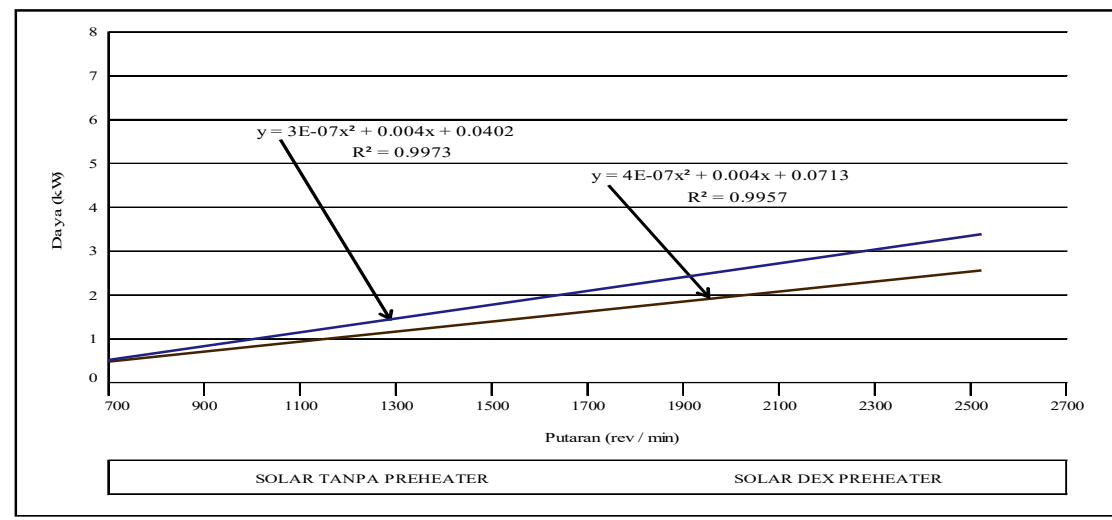

Gambar 9. Daya sebagai fungsi putaran poros motor menggunakan bahan bakar solar dex tanpa preheater dan solar dex dengan menggunakan preheater

Pengukuran data dilakukan pada putaran poros motor $700 \mathrm{rev} / \mathrm{min}$ sampai $2500 \mathrm{rev} / \mathrm{min}$ dengan kenaikan putaran poros mesin $200 \mathrm{rev} / \mathrm{min}$. Terlihat dalam grafik daya bergerak naik dengan bertambah besarnya putaran poros baik menggunakan bahan bakar solar dex tanpa preheater maupun solar dex dengan preheater. Daya dengan bahan bakar solar dex dengan preheater mengikuti persamaan $y=3 \mathrm{E}-07 \mathrm{x}^{2}+0,0004 \mathrm{x}+0,0402$ dengan koefisien korelasi $\mathrm{R} 2=0,9973$. Daya dengan bahan bakar solar dex dengan preheater mengikuti persamaan y $=4 \mathrm{E}-07 \mathrm{x} 2+$ $0,0004 \mathrm{x}+0,0713$ dengan koefisien korelasi $\mathrm{R} 2=0,9957$. Pada putaran $700 \mathrm{rev} / \mathrm{min}$ sampai dengan $1100 \mathrm{rev} / \mathrm{min}$ nilai daya antara bahan bakar solar dex dengan preheater dan solar dex tanpa preheater memiliki nilai daya yang tidak jauh berbeda. Kemudian perbedaan nilai daya antara kedua bahan bakar tersebut meningkat lebih tinggi pada putaran $1500 \mathrm{rev} / \mathrm{min}$ sampai dengan $2500 \mathrm{rev} / \mathrm{min}$. Nilai perbedaan daya tertinggi antara bahan bakar solar dex dengan preheater dan bahan bakar solar dex tanpa preheater terjadi pada putaran $2100 \mathrm{rev} / \mathrm{min}$ dengan peningkatan daya rata-rata meningkat sebesar $12,5 \%$.

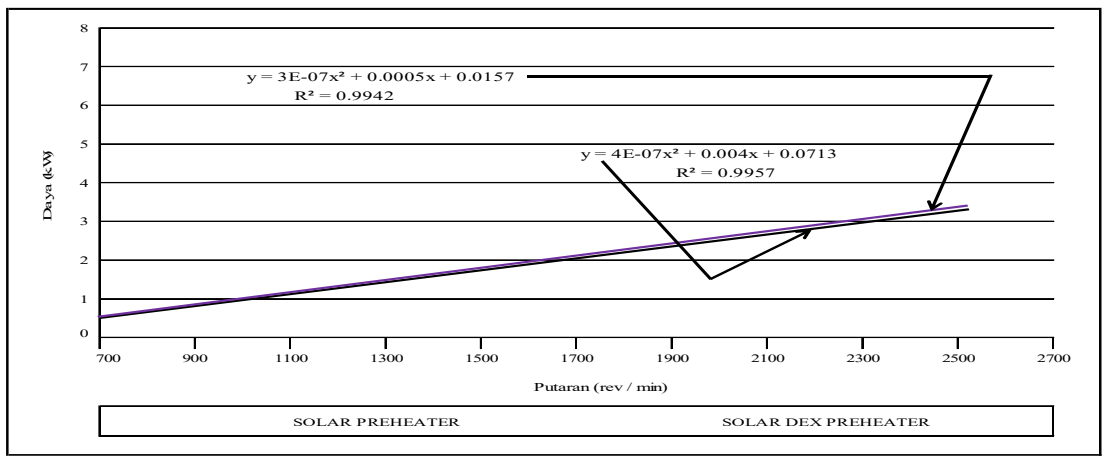

Gambar 10. Daya sebagai fungsi putaran poros motor menggunakan bahan bakar solar dex dengan menggunakan preheater

Pengukuran data dilakukan pada putaran poros motor $700 \mathrm{rav} / \mathrm{min}$ sampai $2500 \mathrm{rev} / \mathrm{min}$ dengan kenaikan putaran poros mesin $200 \mathrm{rev} / \mathrm{min}$. Terlihat dalam grafik daya bergerak naik dengan bertambah besarnya putaran poros baik menggunakan bahan bakar solar dengan preheater maupun solar dex dengan preheater. Daya dengan bahan bakar solar dengan preheater mengikuti persamaan $\mathrm{y}=3 \mathrm{E}-07 \mathrm{x}^{2}+0,0005 \mathrm{x}+0,0157$ dengan koefisien korelasi $\mathrm{R}^{2}=0,0042$. Daya dengan bahan bakar solar dengan preheater mengikuti persamaan $\mathrm{y}=4 \mathrm{E}-07 \mathrm{x}^{2}+0,0004 \mathrm{x}+$ 0,0713 dengan koefisien korelasi $\mathrm{R}^{2}=0,9957$. Pada putaran $700 \mathrm{rev} / \mathrm{min}$ daya antara bahan bakar solar dengan preheater dan solar dex dengan preheater memiliki nilai daya yang 
cenderung sama. Kemudian perbedaan nilai daya antara kedua bahan bakar tersebut meningkat lebih tinggi pada putaran $1300 \mathrm{rev} / \mathrm{min}$ sampai dengan $2500 \mathrm{rev} / \mathrm{min}$. Nilai perbedaan daya tertinggi antara bahan bakar solar dengan preheater dengan bahan bakar solar tanpa preheater terjadi pada putaran $2500 \mathrm{rev} / \mathrm{min}$ dengan peningkatan daya rata-rata sebesar $12,48 \%$. Hal ini terjadi karena bahan bakar yang mengalami pemanasan awal sudah menjadi jenuh dan suhunya menjadi lebih tinggi setelah melewati preheater.

\section{KESIMPULAN DAN SARAN}

Hasil analisis pengaruh pemanasan awal bahan bakar terhadap unjuk kerja motor Diesel dengan bahan bakar solar dan solar dex, dapat diambil kesimpulan sebagai berikut:

1. Torsi sebagai fungsi putaran poros dengan menggunakan pemanasan awal untuk bahan bakar solar lebih besar rata-rata $16,7 \%$ dan untuk bahan bakar solar dex lebih besar ratarata $14,3 \%$.

2. Daya sebagai fungsi putaran poros dengan menggunakan pemanasan awal untuk bahan bakar solar lebih besar rata-rata $14,3 \%$ dan untuk bahan bakar solar dex lebih besar ratarata $12,5 \%$.

3. Pengaruh pemanasan awal terhadap unjuk kerja motor Diesel dengan menggunakan bahan bakar solar dan solar dex lebih baik menggunakan bahan bakar solar dex.

\section{Ucapan Terima Kasih (Acknowledgement)}

Terimakasih sebesar-besarnya kepada: Dosen pembimbing yang telah memberi motivasi dan dorongan kepada penulis menyelesaikan penelitian, Ketua Jurusan Teknik Mesin Fakultas Teknik Dan Sains Universitas Nasional, Kepala Lab. Teknik Mesin dan Sains memberi fasiitas dan pengunaan alat dalam penelitian ini, Para asisten di Lab. Proses produksi dan prestasi mesin di jurusan Teknik mesin dan Sains Universitas Nasional dalam rangka penyelesaian penelitian.

\section{REFERENSI}

Habibie, A.Y, dkk (2015) Analisa pengunaan alat penghemat bahan bakar electrolyzer hho terhadap konsumsi bahan bakar akibat kerugian parasitik pada mesin diesel isuzu panther 2300 cc, Momentum, Vol. 11, No. 1.

Imron, R. dkk (2015) Analisa unjuk kerja mesin diesel kapasitas 132cc pada prototipe cula satu untirta, Jurnal Teknik Mesin Untirta, Vol. I, No. 1.

Sahu, R. At all (2014) Effect of Knocking in Spark Ignition in a Four-Stroke Engin, Ravikant IJMEIT, Vol.2 Issue 1.

Suyanto, W. dkk (2015) karakterisasi bahan bakar pada motor diesel (fuel characterization on diesel engine) Jurnal Penelitian Saintek, Vol. 20, Nomor 1.

Thulasi, V. At all (2013) study of internal flow characteristics of injector fuelled with various blends of diethyl ether and diesel using cfd, Frontiers in Heat and Mass Transfer, vol.4 2.3007 .

Wiranto, A. \& Koichi, T. (1986) Motor Diesel Putaran Tinggi. Pradnya Pratama, Jakarta.

Wiranto, A (1988) penggerak motor bakar torak. ITB, Bandung. 